\title{
Mechanical properties of colored acrylonitrile-butadiene-styrene injection molded parts
}

\author{
Milena Trzaskalska ${ }^{1), *)}$, Paweł Palutkiewicz ${ }^{1)}$, Elżbieta Bociąga ${ }^{1)}$ \\ DOI: dx.doi.org/10.14314/polimery.2018.11.7
}

\begin{abstract}
This article presents the results of examination of processing conditions such as mold $T_{f}$ and injection $T_{w}$ temperature influence on mechanical properties of the moldings made of copolymer ABS (acrylonitrile-butadiene-styrene) without and with a coloring agent in the form of a pigment and its masterbatches. The pigment was added in the amount of $1 \mathrm{wt} \%$ and $2 \mathrm{wt} \%$, while the masterbatches were added in the amount of $1 \mathrm{wt} \%$ and $2 \mathrm{wt} \%$. The mechanical properties of the molded parts were determined in hardness, impact strength and tensile strength tests. The analysis of the obtained results allowed to state that the addition of the coloring agent in a form of pigment does not significantly affect the values of hardness and impact strength. However, the change of the processing conditions, e.g., increasing the mold temperature, contributed to the decrease of hardness and, at the same time, to the increase of impact strength. The tensile strength of the moldings made of ABS without and with the addition of the masterbatch is similar, regardless of the injection molding parameters, whereas their strain at break and Young's modulus change, depending on the injection molding parameters. When using the low values of the mold temperature $\left(30^{\circ} \mathrm{C}\right)$ and injection temperature $\left(230^{\circ} \mathrm{C}\right)$, lower values of Young's modulus were found, however, the aforementioned temperatures allow for obtaining a higher strain at break (noticed for colored samples).
\end{abstract}

Keywords: ABS, coloring agent, injection molding, hardness, impact strength, tensile strength, Young's modulus.

\section{Właściwości mechaniczne barwionych wyprasek z kopolimeru akrylonitryl- -butadien-styren}

Streszczenie: Oceniano wpływ warunków przetwórstwa: temperatury wtryskiwania $T_{w}$ oraz temperatury formy $T_{f}$ na właściwości mechaniczne wyprasek wytworzonych z kopolimeru akrylonitryl-butadien-styren (ABS) bez dodatku i z dodatkiem środka barwiącego w postaci koncentratu lub pigmentu. Koncentrat dozowano w ilości $1 \%$ mas. i 2 \% mas., a pigment w ilości $1 \%$ mas. i 2 \%o mas. Badania właściwości mechanicznych wyprasek obejmowały twardość, udarność i statyczną próbę rozciągania. Na podstawie analizy otrzymanych wyników stwierdzono, że dodatek środka barwiącego nie wpływa w istotnym stopniu na twardość i udarność wyprasek. Natomiast zmiana parametrów przetwórstwa, np. podwyższona temperatura formy, przyczynia się do zmniejszenia twardości, a jednocześnie zwiększenia udarności. Bez względu na warunki przetwórstwa wytrzymałość na rozciąganie próbek z tworzywa ABS bez dodatku oraz $\mathrm{z}$ dodatkiem koncentratu barwiącego była zbliżona, natomiast $\mathrm{w}$ zależności od warunków wtryskiwania następowała zmiana ich odkształcenia przy zerwaniu oraz modułu sprężystości przy rozciąganiu. $\mathrm{W}$ wypadku wyprasek barwionych zastosowanie niskiej temperatury formy wtryskowej $\left(30^{\circ} \mathrm{C}\right)$ oraz niskiej temperatury wtryskiwania $\left(230^{\circ} \mathrm{C}\right)$ powodowało zmniejszenie wartości modułu sprężystości oraz, na ogół, zwiększenie wartości odkształcenia przy zerwaniu.

Słowa kluczowe: ABS, koncentrat barwiący, wtryskiwanie, twardość, udarność, wytrzymałość na rozciąganie, moduł sprężystości.

Polymers which are used in the production of construction elements shall have the high strength properties, hardness, impact strength, wear resistance, etc. [1-6]. The abovementioned characteristics determine the ability of polymers to transmit for example mechanical loads. Mechanical properties depend on two types of factors: internal ones, i.e., the chemical and physical structure of the polymer (the strength of: chemical bonds, intermolecular

1) Czestochowa University of Technology, Faculty of Mechanical Engineering and Computer Science, Department of Polymer Processing, Al. Armii Krajowej 19C, 42-201 Czestochowa, Poland.

*) Author for correspondence; e-mail: trzaskalska@ipp.pcz.pl 
interactions, polymer crosslinks and the degree of crystallinity) and external ones, i.e., the conditions of performance and use of polymer products $[7,8]$. What constitutes an interesting example of widely used amorphous engineering plastics is copolymer acrylonitrile-butadiene-styrene (ABS), which is popular because of its significant characteristics such as good mechanical and processing properties, high stiffness, high impact strength, strong resistance to aggressive media in the place where the detail is used and the ability to achieve high surface quality products. ABS is widely applied in the automotive and aviation industries, in household appliances and home electronics, in parts of office machines, furniture, tubes, sanitation facilities and cases for electrical or other devices. ABS can also be a constituent of many polymer composites $[1,4-6]$. Despite its numerous advantages, it is due to the possibility of modifying its properties that ABS (just like other polymers) gained more potential applications [1, 9-11]. What is applied to achieve this goal are various additives, among which coloring agents are most frequently used. Coloring agents usually do not change the polymer's molecular structure; however what matters here is the form of the dosed agent and its amount. Furthermore, the interphase compatibility between the applied additive and the polymer is also important because mechanical properties of the polymer depend on it $[1,12,13]$. Not only additives but also processing conditions can change the mechanical properties of products made of ABS [14, 15].

The purpose of this paper is to establish the influence of the processing parameters such as the mold temperature $T_{p}$ the injection temperature $T_{w}$, the amount of coloring agent in the form of pigment and its masterbatches on the mechanical properties of the moldings made of copolymer ABS.

\section{EXPERIMENTAL PART}

\section{Materials}

- The tests were conducted on acrylonitrile-butadiene-styrene (ABS) produced by BASF under a trade name Terluran GP 35 Natur.

- Azo pigment Yellow PY 191 and its masterbatches based on ABS and PS (polystyrene) media (the load of pigment amounted to $20 \mathrm{wt} \%$ ) were used as coloring agents. The masterbatch, supplied by Zakłady Chemiczne Permedia Sp. $z$ o.o. from Lublin, was dosed in the amount of $1 \mathrm{wt} \%$ and $2 \mathrm{wt} \%$ and the pigment was dosed in the amount $1 \mathrm{wt} \%$ o and $2 \mathrm{wt} \%$. The plastic was mixed with the pigment in a tight zip lock pouch, which was weighed with the usage of a Sartorius CP 225 scales with accuracy of $\pm 0.01 \mathrm{mg}$ before and after mixing the coloring agent and the polymer, in order to establish the amount of pigment which was left in the package. Pigment PY 191 is characterized by thermal stability in the range from $230^{\circ} \mathrm{C}$ to $280^{\circ} \mathrm{C}$ when used to dye $\mathrm{ABS}$ [16-18]. Neither the plastic nor the masterbatch were predried because they were kept in tight, original bags.

\section{Specimens preparation}

Dumbbell shape specimens type A, compliant with the standard PN-EN ISO 527-2:1998, were produced with the usage of an injection molding machine KM65-160 C4 (Krauss-Maffei). The samples were produced in various injection molding conditions. The processing parameters were selected on the basis of the producer's instructions and scientific literature [19].

Variable processing conditions were specified:

- injection temperature $T_{w}=230^{\circ} \mathrm{C}$ and $250^{\circ} \mathrm{C}$,

- mold temperature $T_{f}=30^{\circ} \mathrm{C}, 50^{\circ} \mathrm{C}$ and $80^{\circ} \mathrm{C}$.

The remaining injection molding parameters were as follows: injection velocity $V_{w}=96 \mathrm{~mm} / \mathrm{s}$, holding pressure $p_{d}=70 \mathrm{MPa}$, injection time $t_{w}=0.8 \mathrm{~s}$, holding time $t_{d}=10 \mathrm{~s}$, cooling time $t_{c h t}=10 \mathrm{~s}$.

The received moldings were used during mechanical properties tests.

\section{Methods of testing}

- Shore's method type D was applied in order to determine the hardness according to the standard PN-ISO $868: 2004$. The hardness was measured in 5 points located on the surface of the molded parts and numbered consecutively according to the direction of the polymer flow.

- Another test was conducted to determine the notched impact strength with the application of Charpy's method and with the usage of a hammer $1 \mathrm{~J}$ (the hammer type), according to the standard PN-EN ISO 179-1:2010. The hardness and impact strength tests were repeated 10 times.

- A tensile strength test was used to determine the strain at break $\varepsilon_{\mathrm{B}^{\prime}}$ tensile strength $\sigma_{\mathrm{M}}$ and Young's modulus $E$. The tensile strength test was conducted at the speed of $10 \mathrm{~mm} / \mathrm{min}$ with the usage of a testing machine Hegewald und Peschke Inspekt Desk 20 (max. 20 kN). The test was repeated 5 times.

The research plan and the markings of moldings produced in different injection moldings conditions are included in Table 1, where MB ABS - means the masterbatch on the basis of ABS, MB PS - is the masterbatch based on PS media and pigm. - means powder pigment.

\section{RESULTS AND DISCUSSION}

The averaged results obtained during the hardness tests with the application of Shore's method type D on samples produced in a variable injection temperature and in a variable mold temperature are presented in Fig. 1.

It is possible to observe that the changes in the hardness of the specimens are caused not only by the pigment and masterbatch added but also by the changed processing conditions. With a low mold temperature $\left(30^{\circ} \mathrm{C}\right)$ almost all the moldings made of uncolored polymer as well as those with the addition of coloring agents are harder than those molded parts which were produced in the higher mold temperature (Fig. 1a). 
T a b l e 1. Experimental research plan

\begin{tabular}{|c|c|c|c|}
\hline $\begin{array}{c}\text { Amount and type } \\
\text { of coloring agent } \\
\text { added to ABS } \\
\text { polymer }\end{array}$ & $\begin{array}{c}\text { Mold } \\
\text { temperature } T_{f} \\
{ }^{\circ} \mathrm{C}\end{array}$ & $\begin{array}{c}\text { Injection } \\
\text { temperature } T_{w} \\
{ }^{\circ} \mathrm{C}\end{array}$ & $\begin{array}{l}\text { Mark of } \\
\text { samples }\end{array}$ \\
\hline 0 & 80 & 230 & A1 \\
\hline 0 & 50 & 230 & A2 \\
\hline 0 & 30 & 230 & A3 \\
\hline 0 & 30 & 250 & A4 \\
\hline $1 \mathrm{wt} \% \mathrm{MB}$ ABS & 80 & 230 & B1 \\
\hline $1 \mathrm{wt} \% \mathrm{MB}$ ABS & 50 & 230 & B2 \\
\hline $1 \mathrm{wt} \% \mathrm{MB}$ ABS & 30 & 230 & B3 \\
\hline $1 \mathrm{wt} \% \mathrm{MB}$ ABS & 30 & 250 & B4 \\
\hline $2 \mathrm{wt} \% \mathrm{MB}$ ABS & 80 & 230 & $\mathrm{C} 1$ \\
\hline $2 w t \% \mathrm{MB} A B S$ & 50 & 230 & $\mathrm{C} 2$ \\
\hline $2 w t \% \mathrm{MB} A B S$ & 30 & 230 & $\mathrm{C} 3$ \\
\hline $2 \mathrm{wt} \% \mathrm{MB}$ ABS & 30 & 250 & $\mathrm{C} 4$ \\
\hline $1 \mathrm{wt} \% \mathrm{MB}$ PS & 80 & 230 & D1 \\
\hline $1 \mathrm{wt} \% \mathrm{MB}$ PS & 50 & 230 & D2 \\
\hline $1 \mathrm{wt} \% \mathrm{MB}$ PS & 30 & 230 & D3 \\
\hline $1 \mathrm{wt} \% \mathrm{MB}$ PS & 30 & 250 & D4 \\
\hline $2 \mathrm{wt} \% \mathrm{MB}$ PS & 80 & 230 & E1 \\
\hline $2 \mathrm{wt} \% \mathrm{MB}$ PS & 50 & 230 & E2 \\
\hline $2 \mathrm{wt} \% \mathrm{MB}$ PS & 30 & 230 & E3 \\
\hline $2 \mathrm{wt} \% \mathrm{MB}$ PS & 30 & 250 & $\mathrm{E} 4$ \\
\hline 1 wt \%o pigm. & 80 & 230 & $\mathrm{~F} 1$ \\
\hline 1 wt $\%$ pigm. & 50 & 230 & F2 \\
\hline 1 wt $\%$ pigm. & 30 & 230 & F3 \\
\hline $1 \mathrm{wt} \%$ pigm. & 30 & 250 & $\mathrm{~F} 4$ \\
\hline 2 wt \%o pigm. & 80 & 230 & G1 \\
\hline $2 \mathrm{wt} \%$ pigm. & 50 & 230 & $\mathrm{G} 2$ \\
\hline $2 \mathrm{wt} \%$ pigm. & 30 & 230 & G3 \\
\hline 2 wt \%o pigm. & 30 & 250 & G4 \\
\hline
\end{tabular}

The injection temperature has less impact upon the hardness of specimens (Fig. 1b). The majority of moldings produced in a variable injection temperature and a low mold temperature $\left(30^{\circ} \mathrm{C}\right)$ were of similar hardness. The increase in the injection temperature caused the decrease in hardness only in the case of the samples dyed with $1 \mathrm{wt} \%$ of the masterbatch on the basis of PS (D4 - D1) and with the pigment $(\mathrm{F} 4-\mathrm{F} 1)$. The research also proved the existence of an influence of the form of the coloring agent on the hardness of the molded parts. In the case of specimens made of ABS with the addition of masterbatch on the basis of PS and of the pigment, the increased amount of coloring agent resulted in the increased hardness, irrespective of the injection conditions, e.g.: for samples dyed with $1 \mathrm{wt} \%$ of the masterbatch on the basis of PS media produced at the mold temperature of $80^{\circ} \mathrm{C}$ the hardness amounted to $73.45^{\circ} \mathrm{Sh}$ (D1), however, when the percentage of the masterbatch grew up to $2 \mathrm{wt} \%$ the hardness grew up to $75.39^{\circ} \mathrm{Sh}$ (E1). The increase in hardness of the moldings made of polymer with the coloring agent, namely the masterbatch on the basis of ABS, accompanied the increase in the amount of the mentioned agent only in the high mold temperature $\left(80^{\circ} \mathrm{C}\right)(\mathrm{B} 1$ and $\mathrm{C} 1)$.

The change of hardness of the molded parts made of ABS with the addition of the masterbatch on the basis of PS, especially if its amounts are higher, can be explained by the presence of polystyrene of different structure and properties than ABS. However, in the case of the specimens made of ABS dyed with the pigment and with the masterbatch on the basis of ABS, it is the crystalline pigment itself that caused a small increase in hardness of the moldings. What should be emphasized, nevertheless, is the fact that the content of coloring agents does not cause significant changes in hardness (between $1 \%$ and $3 \%$ ).

Figure 2 presents the results of the impact tests conducted on the molded parts produced in a variable injection and mold temperature.

It is possible to observe that lowering the mold temperature from $80^{\circ} \mathrm{C}$ to $30^{\circ} \mathrm{C}$ usually contributes to the lower impact strength. However, in the case of the samples made of uncolored polymer as well as those made of ABS with the addition of the masterbatch on the basis of ABS (1 wt \% and $2 \mathrm{wt} \%$ ) and PS (2 wt \%) media the impact strength values are very similar (close to the error tolerance) (Fig. 2a). A significant change of impact strength following the change of the mold temperature occurred in the case of the moldings dyed with $1 \mathrm{wt} \%$ and $2 \mathrm{wt} \%$ of the pigment. Higher values of impact strength were achieved for the abovementioned molded parts in the injection temperature of $250^{\circ} \mathrm{C}$ (Fig. 2b). Higher impact strength (from $6 \%$ to $11 \%$ higher) was observed for the samples made of polymer with the masterbatch on the basis of PS (irrespective of its amount) and 2 wt \%o of the pigment, where the mold temperature was risen to $250{ }^{\circ} \mathrm{C}$ (Fig. 2b).

Furthermore, the rise of the amount of the masterbatch on the basis of PS media contributes to the lower impact strength of the dyed specimens (the impact strength is approximately $20 \%$ lower). This can be caused by the presence of the masterbatch based on PS media whose properties are different than those of the uncolored ABS and by the resulting heterogeneity of the material. In contrast, the rise of the amount of the masterbatch on the basis of $\mathrm{ABS}$ and of the pigment contributes to the increased impact strength value, where the growth is observed by approximately $10 \%$ with the application of the masterbatch (B1, C2) and by approximately $26 \%$ with the application of the pigment (E1, G4). Furthermore, in the case of the moldings made of polymer dyed with the powder pigment whose amount was $1 \mathrm{wt} \%$ and $2 \mathrm{wt} \%$ o the impact strength was similar or higher by approximately $7 \%$ than the impact strength of the samples made of uncolored ABS. Considering the influence of the masterbatch type on hardness and impact strength of moldings it can be stated that it is better to use the coloring agent based on the same copolymer (ABS). However, sometimes the col- 
a)

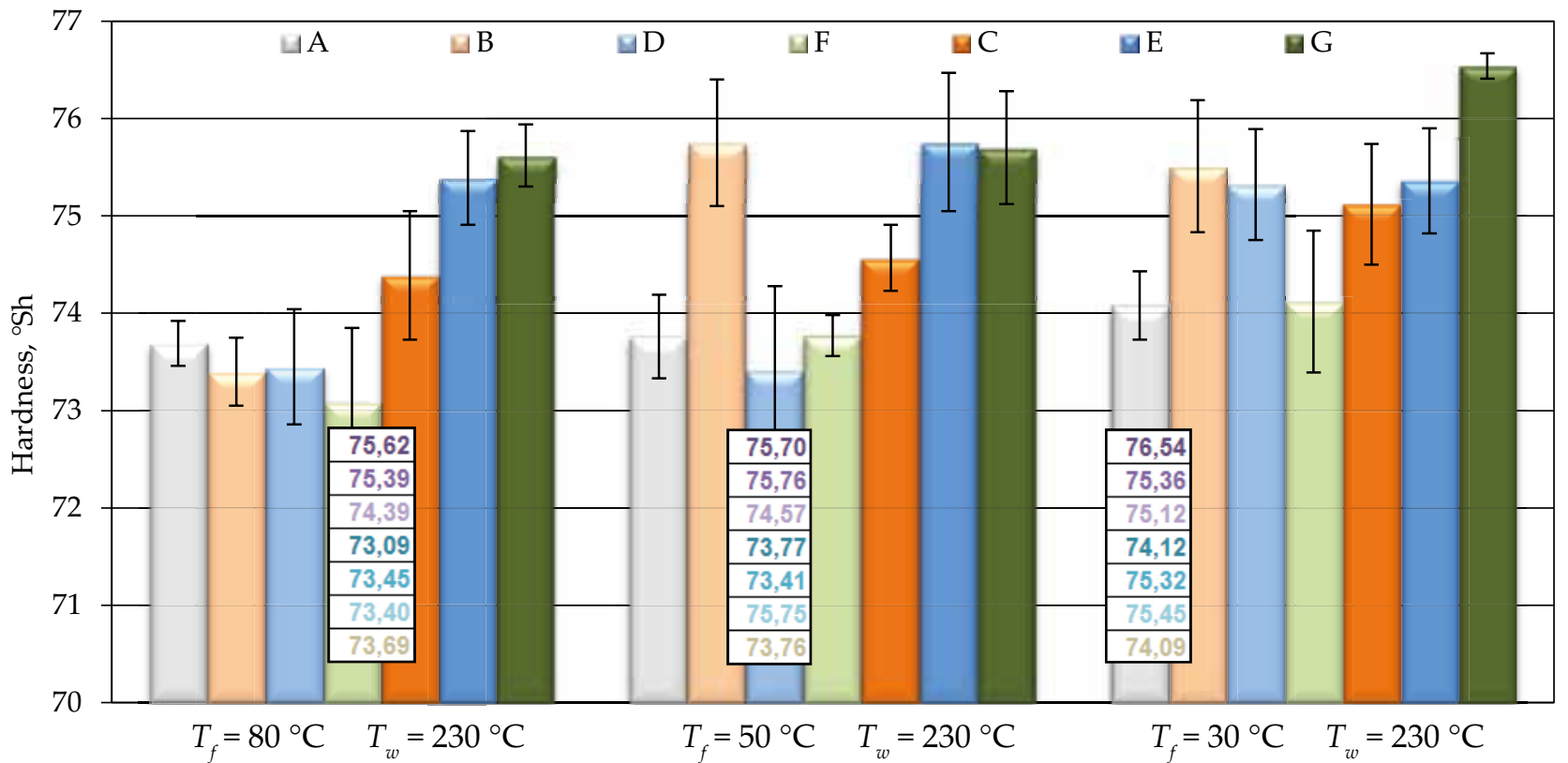

Injection molding conditions

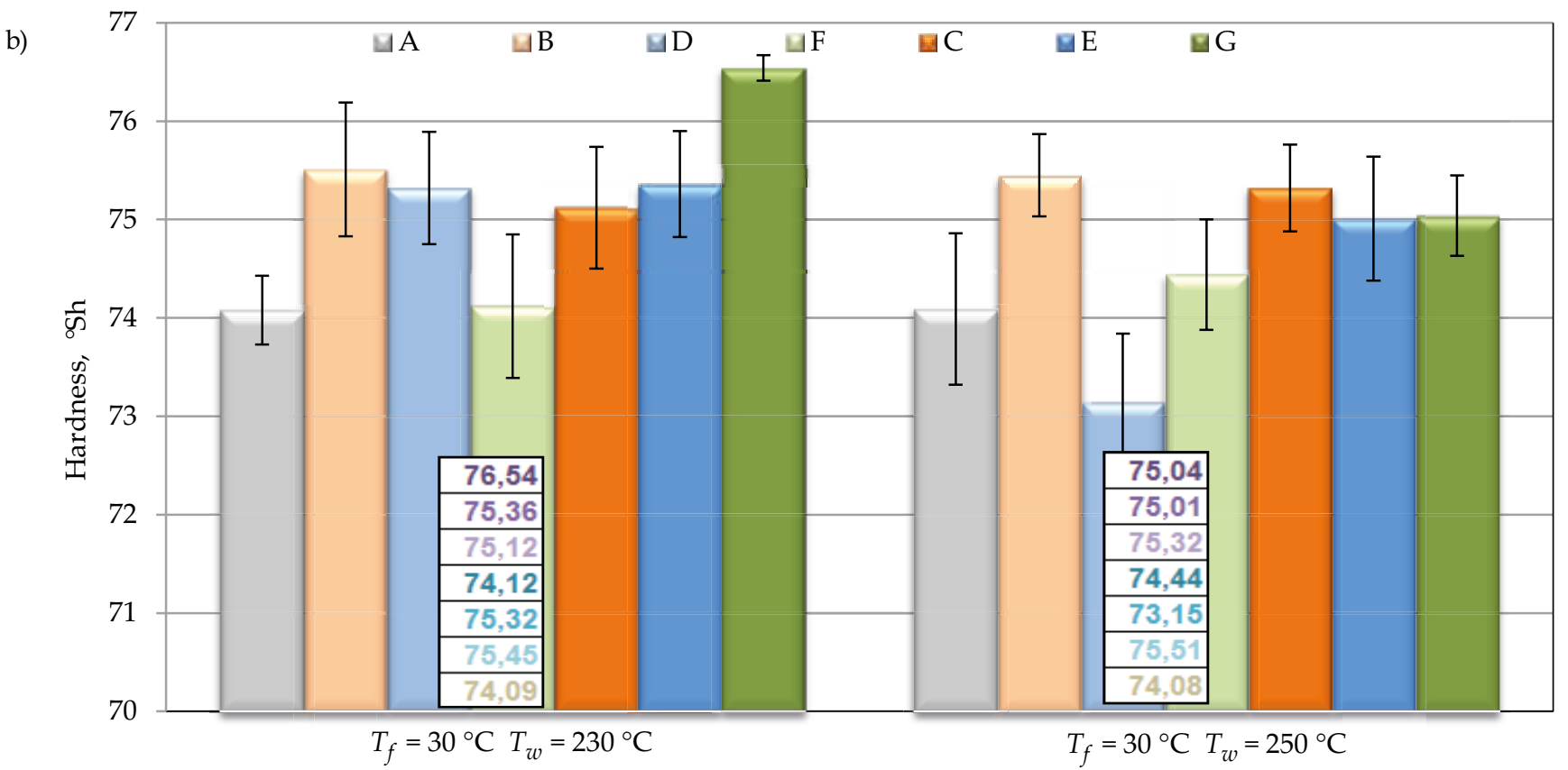

Injection molding conditions

Fig. 1. Influence of: a) mold temperature, b) injection temperature on hardness of moldings determined by Shore D

oring agent based on the different media, but from the same group of polymers (e.g. PS), is used because of the economical purposes.

The averaged results obtained during the tensile tests are presented in Table 2.

Figure 3 presents the comparison of the impact which coloring agents have on the mechanical properties of the moldings made of ABS. At the mold temperature $T_{f}=80^{\circ} \mathrm{C}$ and the injection temperature $T_{w}=230^{\circ} \mathrm{C}$, it is possible to observe that the highest strain at break $\varepsilon_{\mathrm{B}}$ took place in the case of the molded parts made of ABS with the addition of $1 \mathrm{wt} \%$ of the masterbatch on the basis of ABS (B1,
Fig. 3a). Specimens made of ABS dyed with $1 \mathrm{wt} \%$ of the masterbatch on the basis of PS media (D1) are characterized by a slightly lower strain at break. If the amount of the masterbatch is increased to $2 \mathrm{wt} \%$, the strain at break is lower, and it is similar [in the case of the samples made of the polymer with $2 \mathrm{wt} \%$ of the masterbatch on the basis of both PS (E1 - $22.96 \%)$ and ABS media (C1 - $18.34 \%)]$ or slightly lower [in the case of the molded parts made of ABS dyed with 2 wt \%o of the pigment (G1 - $18.66 \%$ )] when compared with the results obtained for the moldings made of uncolored ABS (A1 - 18.89\%). Furthermore, it has been discovered that the tensile strength $\sigma_{M}$ of the 
a)

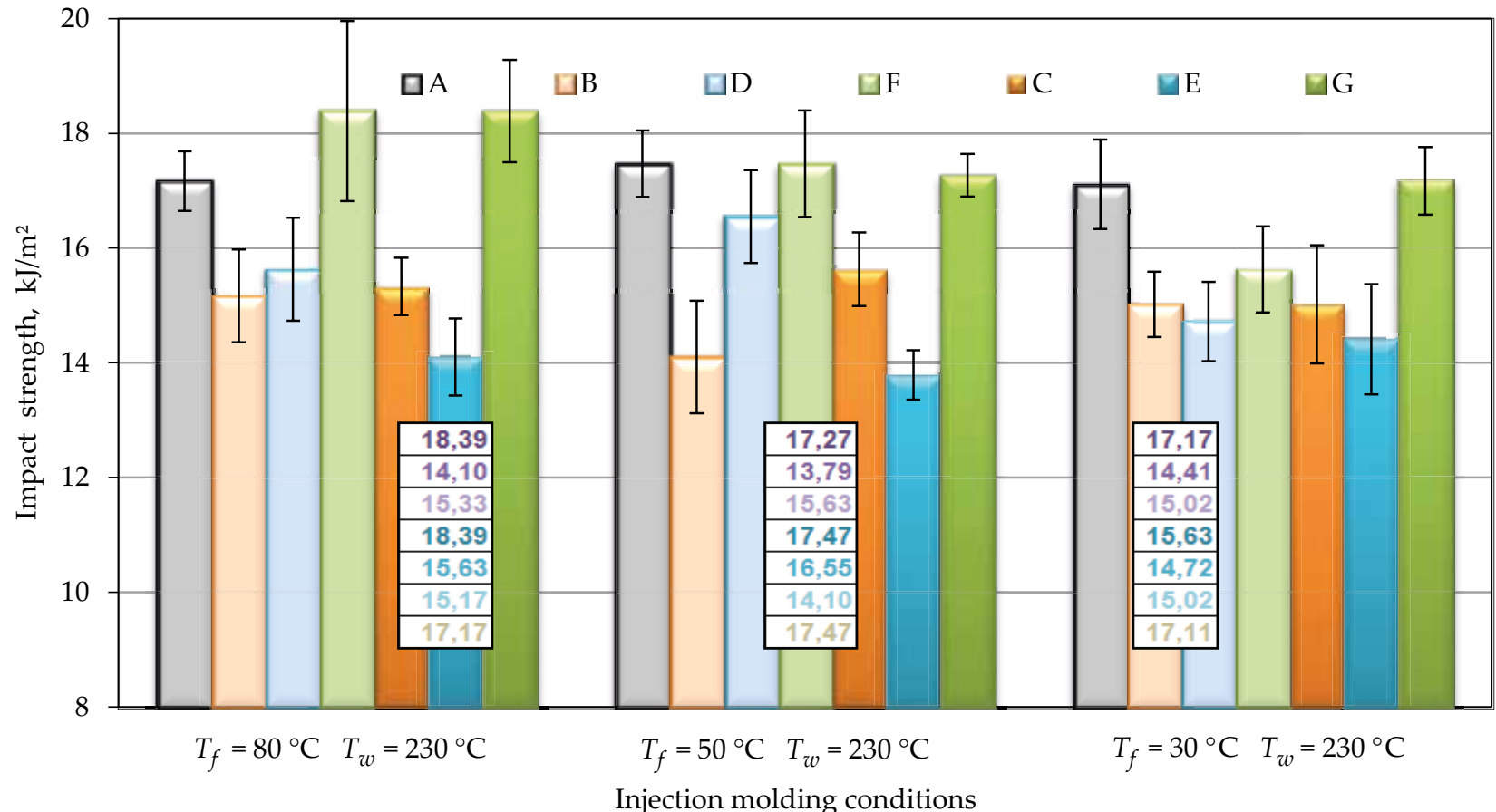

b)

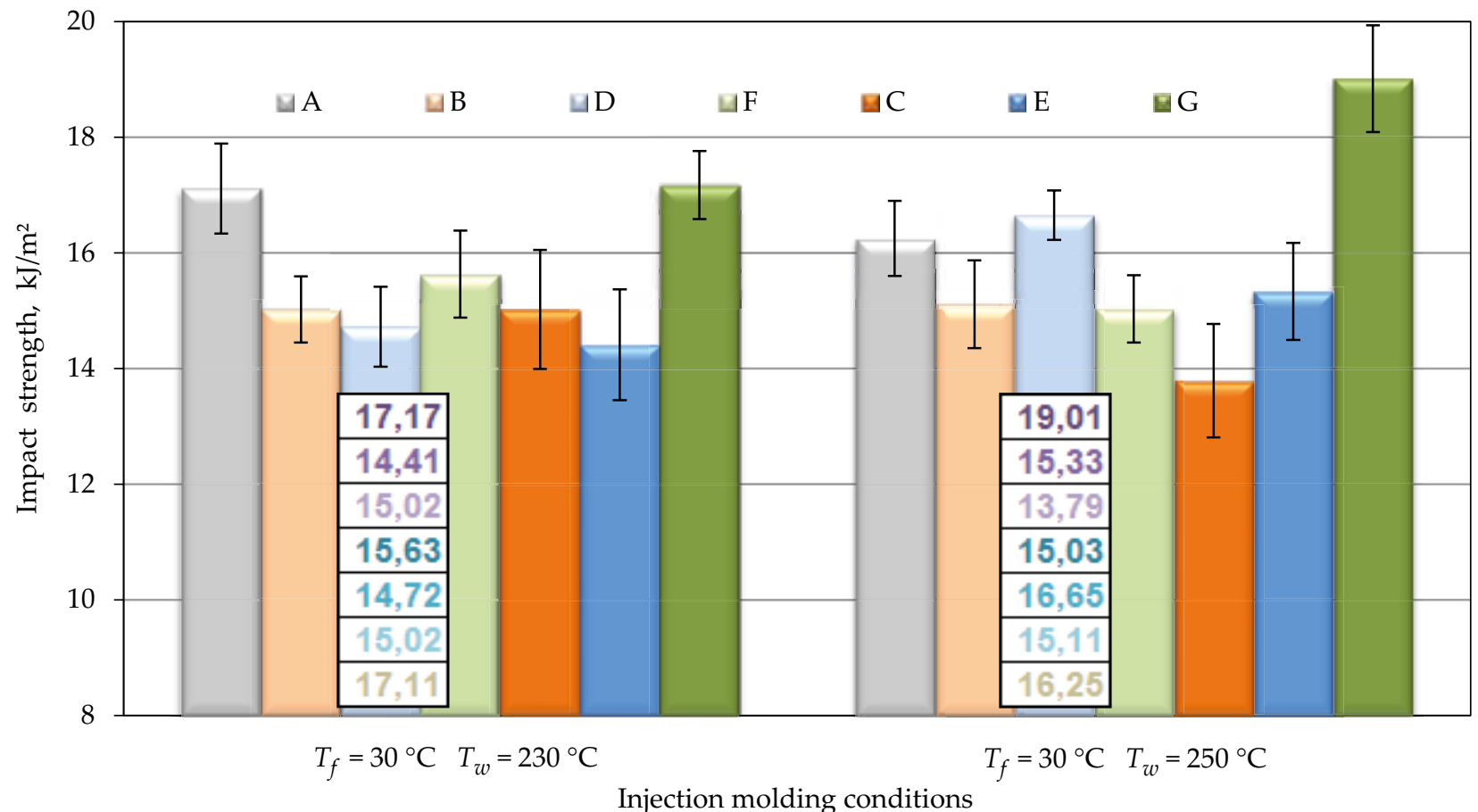

Fig. 2. Influence of: a) mold temperature, b) injection temperature on notched impact strength of moldings determined by Charpy's method

samples made of uncolored polymer and of those which were made of the polymer with the masterbatch (both on the basis of ABS and on the basis of PS media) has a similar value and ranges from 42.36 $\mathrm{MPa}$ (E1) to $45.37 \mathrm{MPa}$ (A1). However, the moldings dyed with the pigment are characterized by a lower tensile strength, which ranges from 39.38 MPa (G1) to $40.60 \mathrm{MPa}$ (F1). Young's modulus $E$ also undergoes mild changes (Table 2). It has been observed that the addition of $1 \mathrm{wt} \%$ of the masterbatch on the basis of ABS contributes to the reduction of the modulus $E$ [from 2372.59 MPa (A1) to 2337.28 MPa (B1)] and that the addition of the masterbatch on the basis of PS results in the increase of its value to $2412.33 \mathrm{MPa}$ (D1) with the application of $1 \mathrm{wt} \%$ of the coloring agent and to $2405.87 \mathrm{MPa}$ (E1) with the application of $2 \mathrm{wt} \%$ of the masterbatch.

With the mold temperature $T_{f}=50{ }^{\circ} \mathrm{C}$ and with the low injection temperature $T_{w}=230^{\circ} \mathrm{C}$ (Fig. 3b) the highest value of strain at break $\varepsilon_{\mathrm{B}^{\prime}}$ amounting to $27.8 \%$, was achieved for the specimens made of uncolored polymer (sample A2). The lowest values of strain at break are specific to the samples made of ABS dyed with the pigment. 
T a b l e 2. Results obtained in static tensile test of moldings made of polymer without and with addition of coloring agent

\begin{tabular}{|c|c|c|c|c|c|c|}
\hline $\begin{array}{l}\text { Mark of } \\
\text { samples }\end{array}$ & $F, \mathrm{~N}$ & $\sigma_{\mathrm{M}^{\prime}} \mathrm{MPa}$ & $\varepsilon_{\mathrm{M}^{\prime}} \%$ & $L_{\mathrm{m}^{\prime}}, \mathrm{mm}$ & $\varepsilon_{\mathrm{B}^{\prime}} \%$ & $E, \mathrm{MPa}$ \\
\hline $\mathrm{A} 1$ & 1814.92 & 45.37 & 15.30 & 6.12 & 18.89 & 2372.59 \\
\hline A2 & 1802.36 & 45.06 & 17.05 & 6.82 & 27.81 & 2347.46 \\
\hline A3 & 1795.52 & 44.89 & 16.45 & 6.58 & 17.98 & 2292.57 \\
\hline $\mathrm{A} 4$ & 1788.22 & 44.71 & 16.24 & 6.49 & 21.44 & 2369.53 \\
\hline B1 & 1798.36 & 43.79 & 17.00 & 6.80 & 24.83 & 2337.28 \\
\hline B2 & 1813.58 & 45.18 & 15.17 & 6.07 & 18.93 & 2395.74 \\
\hline B3 & 1818.86 & 44.49 & 16.22 & 6.49 & 17.49 & 2314.19 \\
\hline B4 & 1799.80 & 44.73 & 15.90 & 6.36 & 22.68 & 2391.18 \\
\hline $\mathrm{C} 1$ & 1751.64 & 44.96 & 16.60 & 6.64 & 18.34 & 2379.10 \\
\hline $\mathrm{C} 2$ & 1807.26 & 45.34 & 16.33 & 6.53 & 24.45 & 2339.03 \\
\hline $\mathrm{C} 3$ & 1779.44 & 45.47 & 16.77 & 6.71 & 18.11 & 2383.28 \\
\hline $\mathrm{C} 4$ & 1789.06 & 44.99 & 15.90 & 6.36 & 23.50 & 2392.68 \\
\hline D1 & 1714.02 & 43.44 & 14.67 & 5.87 & 24.27 & 2412.33 \\
\hline D2 & 1737.72 & 42.77 & 15.32 & 6.13 & 25.18 & 2287.48 \\
\hline D3 & 1742.18 & 43.55 & 14.92 & 5.97 & 23.93 & 2415.06 \\
\hline D4 & 1700.48 & 42.51 & 15.38 & 6.15 & 19.56 & 2401.96 \\
\hline E1 & 1694.28 & 42.36 & 13.52 & 5.41 & 22.96 & 2405.87 \\
\hline E2 & 1693.86 & 42.35 & 13.94 & 5.57 & 20.22 & 2393.40 \\
\hline E3 & 1705.06 & 42.63 & 15.43 & 6.17 & 23.85 & 2362.71 \\
\hline E4 & 1579.30 & 39.48 & 11.28 & 4.51 & 20.85 & 2392.38 \\
\hline $\mathrm{F} 1$ & 1624.14 & 40.60 & 13.18 & 5.27 & 14.35 & 2374.72 \\
\hline F2 & 1614.22 & 40.36 & 11.68 & 4.67 & 21.54 & 2390.79 \\
\hline F3 & 1544.72 & 38.62 & 11.38 & 4.55 & 11.54 & 2336.48 \\
\hline $\mathrm{F} 4$ & 1547.92 & 38.70 & 11.90 & 4.76 & 14.95 & 2361.20 \\
\hline G1 & 1575.16 & 39.38 & 11.98 & 4.79 & 18.66 & 2377.61 \\
\hline G2 & 1551.84 & 38.80 & 12.65 & 5.06 & 12.88 & 2317.03 \\
\hline G3 & 1701.32 & 42.53 & 12.92 & 5.17 & 19.64 & 2405.08 \\
\hline G4 & 1472.76 & 36.82 & 10.25 & 4.10 & 11.05 & 2404.99 \\
\hline
\end{tabular}

$F$ - maximum force, $\sigma_{\mathrm{M}}-$ tensile strength, $\varepsilon_{\mathrm{M}}-$ strain at maximum force, $L_{\mathrm{m}}-$ maximum elongation, $\varepsilon_{\mathrm{B}}-$ strain at break, $E-$ Young's modulus.

They amounted to $21.54 \%$ (F2) and $12.88 \%$ (G2) respectively for the polymer with $1 \mathrm{wt} \%$ or $2 \mathrm{wt} \%$ of the pigment. In the case of ABS dyed with the masterbatches the values of the strain at break ranged from $18.93 \%$ (sample $\mathrm{B} 2$ with the addition of $1 \mathrm{wt} \%$ of the masterbatch on the basis of ABS media) to $25.18 \%$ (sample D2 - ABS dyed with $1 \mathrm{wt} \%$ of the masterbatch on the basis of PS). While analyzing the values of tensile strength $\sigma_{\mathrm{M}^{\prime}}$ the researchers observed the tendencies similar to the ones which exist at the high mold temperature. Furthermore, the increase in the amount of the masterbatch on the basis of ABS as well as the increase in the amount of the pigment causes lower values of Young's modulus E. A contrary tendency was observed for the molded parts made of polymer dyed with the masterbatch on the basis of PS media.

What was observed in the case of the moldings produced in the low mold temperature $\left(30^{\circ} \mathrm{C}\right)$ and in the low injection temperature $\left(230^{\circ} \mathrm{C}\right)$ (Fig. 3c) was the fact that the high- est value of strain at break $\varepsilon_{\mathrm{B}}$ was obtained for the specimens made of ABS dyed with the masterbatch on the basis of PS (irrespective of its amount). The application of $1 \mathrm{wt} \%$ of the masterbatch on the basis of ABS and $1 \mathrm{wt} \%$ of the pigment to dye the samples results in the value of strain at break which is lower than the value of strain at break for the molded parts made of uncolored polymer. However, the increase of the coloring agent in the aforementioned forms contributes to the production of moldings whose strain at break is higher than the one of the specimens made of uncolored ABS. The tensile strength of the molded parts made of uncolored polymer is similar to the tensile strength of the specimens dyed with the masterbatches and it ranges from $42.53 \mathrm{MPa}(\mathrm{G} 3)$ to $45.47 \mathrm{MPa}(\mathrm{C} 3)$. A slightly lower value, namely $38.62 \mathrm{MPa}$ (F3), was achieved in the case of the samples dyed with $1 \mathrm{wt} \%$ of the pigment. The addition of the coloring agent results in the increase by approximately $1-5 \%$ of Young's modulus $E$, irrespective of the amount or form of the mentioned agent. 

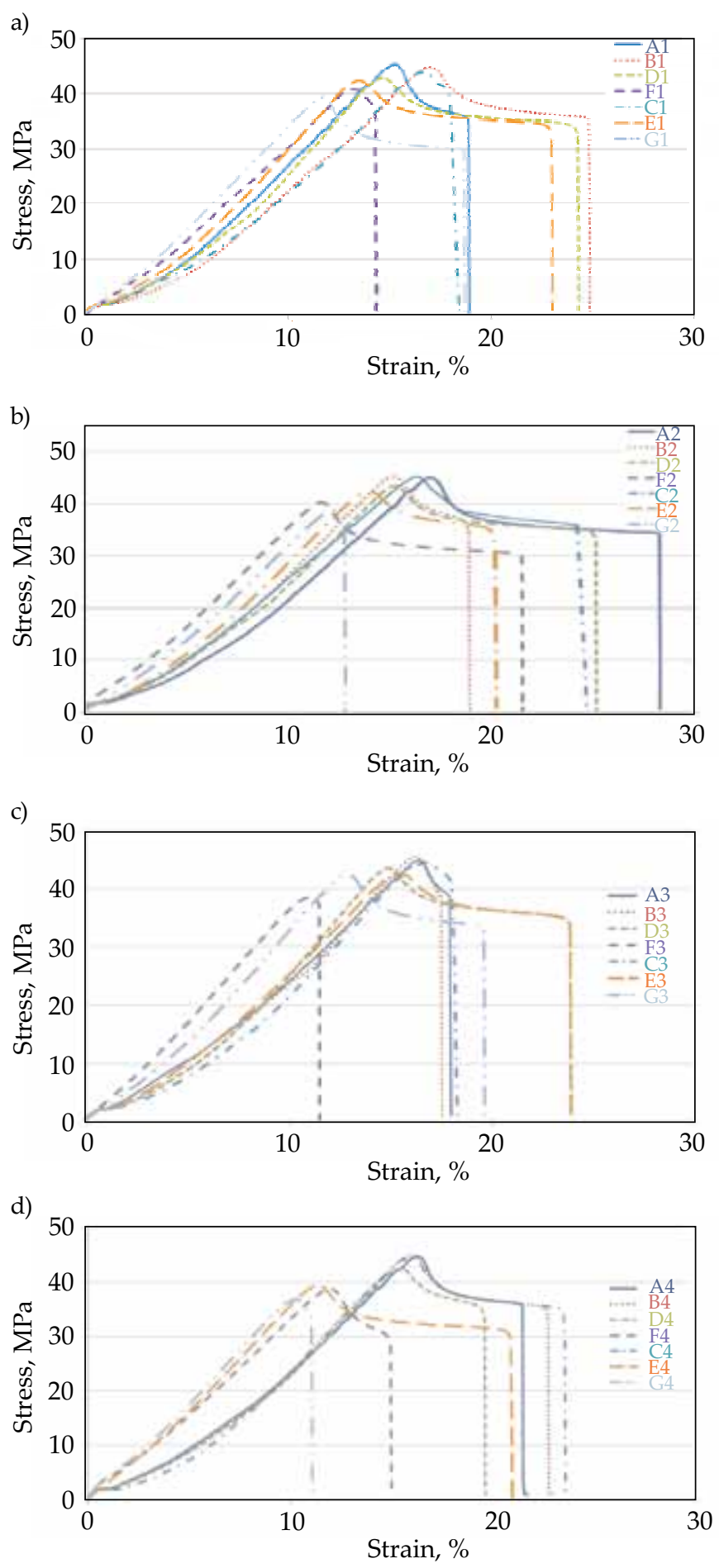

Fig. 3. Stress-strain curves received for moldings made of ABS without and with addition of coloring agent produced by following processing conditions: a) $T_{f}=80^{\circ} \mathrm{C}$ and $T_{w}=230^{\circ} \mathrm{C}$, b) $T_{f}=50^{\circ} \mathrm{C}$ and $T_{w}=230{ }^{\circ} \mathrm{C}$, c) $T_{f}=30^{\circ} \mathrm{C}$ and $T_{w}=230{ }^{\circ} \mathrm{C}$, d) $T_{f}=30^{\circ} \mathrm{C}$ and $T_{w}=250^{\circ} \mathrm{C}$

It has been established that with the application of the low mold temperature $T_{f}=30^{\circ} \mathrm{C}$ and the high injection temperature $T_{w}=250^{\circ} \mathrm{C}$ (Fig. 3d) the addition of the masterbatch on the basis of ABS media and the increase of its amount to $2 \mathrm{wt} \%$ contribute to the increase in the value of strain at break $\varepsilon_{\mathrm{B}^{\prime}}$ in comparison to the strain at break of the uncolored samples where $\varepsilon_{\mathrm{B}}=21.44 \%$.
However, the addition of the remaining coloring agents causes lower values of strain at break. The lowest values of strain at break, which amounted to $14.95 \%$ (F4) and $11.05 \%$ (G4), were observed in the case of the moldings dyed with $1 \mathrm{wt} \%$ and $2 \mathrm{wt} \%$ of the pigment. The molded parts dyed with the masterbatch on the basis of ABS media (irrespective of the amount) are characterized by the tensile strength similar to the one achieved for the moldings made of uncolored polymer. The application of the pigment and of the masterbatch on the basis of PS media causes lower tensile strength. The values of tensile strength decrease with the increasing amounts of the aforementioned coloring agents. For example the tensile strength of the samples made of ABS dyed with $2 \mathrm{wt} \%$ of the pigment (G4) was $18 \%$ lower that the tensile strength of the moldings made of uncolored polymer (A4). At the same time, the addition of the coloring agent usually contributes to the increase of Young's modulus E.

\section{CONCLUSIONS}

The performed measurements helped to demonstrate the influence of the processing conditions, i.e., the injection temperature $T_{w}$ and the mold temperature $T_{f}$ on the mechanical properties of the moldings made of colored copolymer ABS.

What was observed was a slight increase of Shore's hardness type D for the specimens made of ABS with the masterbatch on the basis of ABS and with the pigment. A decrease in hardness was observed in the case of the molded parts dyed with the masterbatch on the basis of PS. A higher influence on the hardness of the samples was visible when the processing conditions, i.e., the mold temperature $T_{f}$ and the injection temperature $T_{w,}$ were changed.

The coloring agent in the form of the masterbatch usually causes the decrease of the impact strength of the moldings. However, the specimens made of ABS dyed with the pigment are characterized by almost the same, or higher, impact strength as the uncolored samples.

The tensile strength tests proved that the molded parts made of uncolored ABS and those made of ABS dyed with the masterbatch on the basis of ABS media (irrespective of the processing conditions) are characterized by a similar tensile strength $\sigma_{\mathrm{M}}$. The addition of the coloring agent in the form of the masterbatch on the basis of PS and of the pigment contributes to the decrease of the tensile strength (even by $18 \%$ in the case of series G4). Furthermore, what was demonstrated in the case of the dyed moldings was that the increase of the amount of the masterbatch on the basis of ABS usually contributes to the increase of the value of strain at break $\varepsilon_{B}$, but the addition of a higher amount of the masterbatch on the basis of PS usually results in the decrease of the aforementioned value. The maximum value of strain at break was observed in the majority of cases for the samples produced at the mold temperature of $50{ }^{\circ} \mathrm{C}$ and at the injec- 
tion temperature of $230^{\circ} \mathrm{C}$. Young's modulus E, however, undergoes relatively minor changes as a result of the addition of the coloring agents or as a result of the change in the processing conditions.

The changes of strain at break and tensile strength may result from the load/charge given during the tensile strength test. Macromolecules of the stretched moldings turn, straighten and move with respect to each other and sometimes the rupture of macromolecules can take place as a consequence of this process. The ease with which macromolecules move with respect to each other largely depends on the structure and orientation of the polymer, the abovementioned structure being achieved as a result of the processing of the polymer.

The changes of the value of strain at break and tensile strength may be caused not only by the processing conditions but also by the structure of the masterbatch. The coloring masterbatches include in their composition not only base materials and color pigments but also optical brighteners (e.g., titanium white, $\mathrm{TiO}_{2}$ ) and aids such as stabilizers, homogenization aids, plasticizers, etc. Even a small addition of those substances may contribute to significant changes in the mechanical properties.

\section{REFERENCES}

[1] Bociąga E., Postawa P., Trzaskalska M.: Przetwórstwo Tworzyw 2012, 18 (3), 143.

[2] Hyla I.: „Tworzywa sztuczne. Własności Przetwórstwo - Zastosowanie", Wydawnictwo Politechniki Śląskiej, Gliwice 2000.

[3] Nicholson J.W.: „Chemia polimerów”, Wydawnictwa Naukowo - Techniczne, Warszawa 1996.

[4] Żenkiewicz M.: „Tworzywa wielkocząsteczkowe. Polimeryzacja - właściwości - badania", Wydawnictwo Akademii Bydgoskiej, Bydgoszcz 2002.

[5] Żuchowska D.: „Polimery konstrukcyjne. Wprowadzenie do technologii i stosowania", Wydawnictwa Naukowo - Techniczne, Warszawa 1995.
[6] Seachtling H.: „Tworzywa sztuczne. Poradnik”, Wydawnictwa Naukowo - Techniczne, Warszawa 2000.

[7] Bociąga E., Trzaskalska M.: Color Research and Applications 2016, 41, 392.

http://dx.doi.org/10.1002/col.21971

[8] Bociąga E., Jaruga T.: Journal of Achievements in Materials and Manufacturing Engineering 2007, 23, 83.

[9] Bortel K.: Tworzywa Sztuczne w Przemyśle 2011, 5, 14.

[10] Color Tone: Guide Coloring plastics with masterbatch, http://www.colortone-masterbatch.co.uk/pages/technical.html (access date: 30.01.2018)

[11] Koszkul J.: „Materiały polimerowe” (Ed. Koszkul J.), Wydawnictwo CWA Regina Poloniae, Częstochowa 2010, pp. 59-72.

[12] Özkan Gülsoy H., Münir T.: Polymer-Plastics Technology and Engineering 2007, 46, 789. http://dx.doi.org/10.1080/03602550701274185

[13] Cheang P., Khor P.A.: Material Science and Engineering 2003, 345, 47. http://dx.doi.org/10.1016/S0921-5093(02)00284-8

[14] Trzaskalska M.: „Analiza oddziaływania środków barwiących na wybrane właściwości fizyczne i użytkowe wyprasek $\mathrm{z}$ terpolimeru ABS", PhD thesis, Częstochowa 2015.

[15] Lee J.K., Scott Ch.E., Virkler T.L.: Polymer Engineering and Science 2001, 41, 240. http://dx.doi.org/10.1002/pen.10725

[16] Ivashevskaya S.N., van de Streek J., Djanhan J.E. et al.: Acta Crystallographica Section B 2009, 65, 212. http://dx.doi.org/10.1107/S0108768109001827

[17] Hunger K.: Review of Progress in Coloration and Related Topics 1999, 29, 71. http://dx.doi.org/10.1111/j.1478-4408.1999.tb00129.x

[18] Müller A.: "Coloring of Plastics. Fundamentals - Colorants - Preparations", Carl Hanser Verlag, Munich 2003.

[19] Zawistowski H., Zięba S.: „Ustawianie procesu wtrysku", Wydawnictwo Plastech, Warszawa 1995.

Received 18 I 2018. 